\title{
4+4+4 Eğitim Sisteminin Beşinci Sınıf Öğrencilerine Yansıması: Öğretmen Görüşleri1
}

\section{Reflection of the 4+4+4 Education System on the Fifth Grade Students: Teacher Opinions}

\author{
Emine Gül Özenç², Yrd. Doç. Dr., Niğde Ünivesitesi Eğitim Fakültesi, egozenc@nigde.edu.tr \\ Zeynel Ersin Özcan, Sinı Öğretmeni, Hasaköy Șehit Cemal Özcan İlkokulu zeynelersin.ozcan@gazi.edu.tr \\ Feramuz Güçlü, Müdür Yardımcısı, Bağlama Şehit Adnan Savaş İlkokulu, feramuz51@gmail.com \\ Ebru Keser Güney, Sınıf Ögrretmeni, Toki Hadımköy Illkokulu , Arnavutköy, ebrukeser@hotmail.com
}

\begin{abstract}
öZ. Bu çalışmanın amacı 4+4+4 eğitim sistemiyle birlikte ortaokul olan 5. Sınıf öğrencilerinin yaşadığı problemlerin öğretmen görüşleri açısından ele alınmasıdır. Araştırmanın örneklemini 2013-2014 eğitim ve öğretim yılı, Niğde ili 147 beşinci sınıf branş öğretmenleri oluşturmaktadır. Araştırmada nitel ve nicel araştırma yöntemleri bir arada kullanılmıştır. Elde edilen açık uçlu anket sorularından en temel görüşler; öğrenci kaynaklı olduğu düşünülen sorunların kısaca, öğrencilerin yaşlarının küçük olduğu, kendilerini ilkokul gibi hissettikleri, ergenlik çağındaki çocuklarla bir arada olmalarının sakıncalı olabileceği, derslere ilgisiz oldukları yönündedir. öğretmen kaynaklı olduğu düşünülen sorunların öğrencilerin davranışlarını yönetememe (sınıf ve davranış yönetimi), ders anlatım yöntem ve tekniklerinde hissedilen eksiklikler, haftalık ve günlük ders saatlerinin fazlalığı ile derslere giriş-çıkış saatleri şeklinde yoğunlaşmıştır; diğer etmenler olarak kısaca ders saatlerinin fazlalığı, giriş çıkış saatlerinin uygun olmayışı, ders kitapları ve müfredat programının uygun olmadığı ve son olarak açlıkla başedememe olarak dile getirilmiştir. Bunlara ek olarak nicel bulgular da bu sonuçları destekler niteliktedir.
\end{abstract}

Anahtar kelimeler: 4+4+4 eğitim sistemi, 5. Sınıf öğrencileri, öğretmen görüssleri.

\begin{abstract}
The purpose of this research is to determine the problems about fifth grade students, considered as in primary school who has been shifted to secondary school with the $4+4+4$ education system. The sample of the research is 147 branches teacher teaching in 2013-2014 academic year in Niğde. Qualitative and quantitative research methods together were used in this study. Results obtained from open-ended questionnaire shows that the main problems stemming from students are that; the age of students is small, they feel themselves as primary, being with children in adolescence may be inconvenient for fifth grade, they are unrelated to the course; problems stemming from teachers; inability to manage the behavior of students, lack of technical lecture method excess of the weekly and daily hours, entry and exit hours; problems stemming from other factors are; excess of lesson hours, unsuitability of entry and exit times, textbooks and curriculum are not appropriate and finally inability to cope with hunger. In addition, the findings of the quantitative data are supporting these results.

Keywords: $4+4+4$ education system, 5 th grade students and teacher opinions.
\end{abstract}

\section{SUMMARY}

Purpose and Significance: Some changes have been made in education with $4+4+4$ education system. Fifth grade students, considered as in primary school, have been shifted to secondary school. From this respect it has been thought that there are some problems for 5 th grades so from this point of view the purpose of the study is the overall evaluation of experienced problems with 5th Grade in the light of the views of teachers after changes with $4+4+4$ education system.

Methodology: The research has been carried out in 2013-2014 academic year with teachers of different branches, working in Niğde secondary schools $(n=147)$. Some of the teachers $(n=34)$ participating in the research have completed the open-ended questionnaire, the remaining portion of teachers $(n=113)$ have answered triple Likert type questionnaire. In the study, mixed research method, that is a combination of Qualitative and quantitative research methods, is preferred. Descriptive analysis, frequency and percentage tables are used in the study. The questionnaire

${ }^{1}$ This study has been presented as oral presentation in 24th National Congress of Educational Sciences (16-19 April 2015, Nigde).

${ }^{2}$ Corresponding author, Assist. Prof. Dr., Niğde University Faculty of Education 
developed by the researchers; consists of 30 items and three sub-factors. Also, the total cronbach's alpha coefficient of the questionnaire is calculated as $0.86(\alpha=.862)$, the sub-factors are calculated as $0.80(\alpha=.798)$ for students factor, $0.72(\alpha=.720)$ for teachers factor, $0.71(\alpha=.713)$ for the others.

Results: Research findings obtained from the questions of open-ended questionnaire shows that teachers' opinion about problems stemming from students in short are; that the age of students is small, they feel themselves as primary, being with children in adolescence may be inconvenient for fifth grade, they are unrelated to the course, motivation and attention deficit problems, behavioral disorders. Teachers said that "They are not interested in lessons", "their age is not suitable as a secondary", "adjustment process became longer", "They could not get used to come to school early", "They find it difficult to get used to lots of teachers".

Problems stemming from teachers in short are; inability to manage the behavior of students, lack of technical lecture method excess of the weekly and daily hours and entry and exit hours. General opinion of teachers is that grade 5 lived a transition period in the first semester. However, It is reported that the process is exceeded at a time and almost back to normal. Teachers expressed the view that "I can't take care of the students one by one", "I have difficulty to descend to the level of students", "I do not draw their attention to the course". Problems stemming from other factors in short are; excess of lesson hours, unsuitability of entry and exit times, textbooks and curriculum are not appropriate and finally inability to cope with hunger. Teachers expressed the view that "seven hour lesson is too much", "school entry time is very early", "inadequate curriculum" "too many abstract concepts in the textbooks", "when the students come very early, they cannot cope with hunger."

The most noteworthy ones from the data obtained quantitatively listed in the following way: The issues that are thought to be students originated; A lot of childish behavior of students $(\% 84,1)$, They feel themselves as primary (\%77), being with children in adolescence may be inconvenient for fifth grade $(\% 73,5)$, students are in a concrete period $(\% 63,7)$. The issues that are thought to be teachers originated; Age is more suited to be primary $(\% 61,1)$, they don't have one to one attention so they are alienated from school $(\% 36,3)$, subject teachers are needed $(\% 31,9)$. As other factors ; They become hungry more often $(\% 70,8)$, Entry and leaving hours are not suitable $(\% 67,3), 7-8$ lessons comes more $(61,1)$.

\section{GÍRIS}

Zaman içerisinde toplumlarda eğitimin konusu; mükemmel olmayanı mükemmelleştirilmek için eğitilen insandır. Aynı zamanda insan oluş halinde olan, gelişen, değisşen, eğitimden etkilenen, davranışları düzene sokulan veya değiştirilebilen varlıktır (Ergün, 1999). Eğitim insanlar için olduğu kadar ülkelerin gelecekleri için de en önemli unsurlardan birisidir. Bu nedenle gelişmiş, gelişmekte olan ve geri kalmış ülkelerin eğitim alanında sürekli olarak iyileştirme çalışmaları ve çabaları olmaktadır. Sonuç olarak ise eğitim alanında gerçekleştirilen reform ve çalışmalar ile eğitim ve eğitimle dolaylı veya direkt alakalı tüm alanlarda, yakın veya uzak hedef olarak iyileşme beklenmektedir.

Başka bir değişle eğitim alanında elde edilen ivmenin diğer tüm alanlar için kaynak oluşturması beklenmektedir. $\mathrm{Bu}$ sayede toplumu dönüştürme ve geliștirme çabası kendisini göstermiş olmaktadır. Toplumun da bireylerden beklentileri zamana bağlı olarak değișim gösterir. Değişim, sosyal, kültürel, politik, ekonomik yönleri olan karmaşık bir süreçtir. (Huczeynski ve Buchananan, 1991). Bu değișime hızlı şekilde cevap vermesi gereken hatta bu değișimin bizzat yönlendiricisi olarak görülebilecek yegane alan eğitim alanıdır. Nitekim Özdemir'e (2000) göre gerek bilgi toplumuna geçmiş toplumlarda gerekse geçiş sıkıntılarının yaşandığı toplumlarda eğitim kurumları odak nokta olma özelliğini devam ettirmektedir. Bu bakımdan eğitimde yenileşme hareketleri, öğretim programları yada planlama çalıșmaları nitelik ve süreklilik arz etmesi açısından bir gereklilik olarak görülebilir. Dolayısıyla yapılan veya yapılması planlanan çalıșmaların temelinde "iyileşme", "daha iyiyi yakalama" , "modernize olma", "değişim veya dönüşüm" gibi durumlar bulunmaktadır diyebiliriz. 
Eğitim alanında yapılmış veya yapılacak olan değişikliklerin doğrudan veya dolaylı olarak ülkelerin çıkarlarını koruyacak nitelikte ve geleceklerini garanti altına alacak özellikte olması beklenir. Yapılacak değişiklikler gerçek hayatta ve uygulamada kendisine yer bulamazsa, bireylerin ve toplumsal yaşantının beklenen yönde olmayacağı açıktır. Dolayısıyla yapılacak değişiklikler anlık değişimlere cevap verir nitelikte olursa süreklilik sağlanamayacaktır. Yenileşme ve geliştirme hareketleri, ilerlemeleri takip eden, farklılıkların öncülü ve kalıcı değişimler sağlayacak biçimde gerçekleştirilmelidir.

\section{Türkiye'de İlköğretim Süresindeki Değişimler ve Eğitime Genel Bir Bakış}

Eğitimde yenilik ve değișim dediğimizde, ilköğretim alanında Türkiye'de Cumhuriyet tarihi boyunca gerçekleştirilmiş değişimlerin ve çalışmaların kısaca ele alınması doğru olacaktır. Ancak ele alma biçimimiz genel ifadeler ve daha çok ilköğretimin süresi ile ilgili değişiklikler olacaktır. Türkiye'de eğitim, batılı eğitim anlayış ve değerlerinin gölgesinde șekillenmiştir ve șekillenmeye de devam etmektedir. Osmanlı'dan itibaren başlayan çalışmaların öncelikle Avrupa ülkelerini takip eder nitelikte olduğu görülür. 1950'li yıllardan itibaren ise Amerika'nın daha önemli bir model olarak göze çarptığından bahsedilebilir. Her ne yönde olursa olsun Türk eğitim sisteminde iyileştirme, işler hale getirme veya işlemeyeni atma çabası bulunmaktadır.

Bu doğrultuda Tevhid-i Tedrisat (Öğretim Birliği Yasası) Kanunu'nu ele alarak başlamak faydalı olacaktır. 1924 yılında John Dewey'e eğitimin sorunları ve çözümleri konusunda iki ay inceleme yaptırılarak alınan rapor doğrultusunda 1924'te Tevhid-i Tedrisat Kanunu kabul edilmiştir (Akyüz, 1994). 1924 yılına baktığımızda ilkokul süresinin 5 yıl olarak belirlendiğini görmekteyiz (Fer, 2005). 1926 yılında Talim ve Terbiye Kurulu kurulmuştur. Yine 1926 yılında ise beş yıllık olan ilkokulun birinci (ilk üç sene) ve ikinci kademe (son iki sene) olmak üzere iki kısımda ele alındığını görmekteyiz (Gözütok, 2003). Değinilmesi gereken bir nokta ise ilkokulların köyde ilk kademesinin bulunuyor olmasıdır. Bu durumdan 1938 yılındaki değişikliklerle vazgeçilecekti. Bu yıl ve bu yıla kadar yapılan çalışmalarda ilkokul öğrencilerinin gelişim özellikleri dikkatle ele alınmış görünmektedir (Fer, 2005).

Yakın geçmiște ilk ve ortaokullar 1997 yılı ve 4306 sayılı Kanun'la sekiz yıllık zorunlu temel eğitim șeklinde birleștirilmiștir. Yani bu yıldan itibaren artık ilk ve orta olmak üzere iki kademe bulunmuyor, bu kademeler "ilköğretim" adı altında birleştiriliyordu. İlköğretim iki kademe olarak ele alınıyor, ilköğretim birinci kademe daha önceden bildiğimiz ilkokul, ikinci kademe ise ortaokula karşıllk geliyordu. Bununla beraber ilkokula başlayan bir öğrenci sekiz yıl ilköğretim kademesinde öğrenim görecekti.

Bu değişimleri takiben 2005 yılında kabul edilen program geliştirme çalışmaları önemli değişiklikler olarak adlandırılabilir. Ancak konumuzla bağlantısı program geliştirme açısından değil de, ilköğretimin süresi ve şekli ile ilgili olduğu için detaylı olarak değinilmemiştir. Önemli bir işleyiş farklılığı olarak kılavuz kitap anlayışı eğitime dahil olmuştur ve halihazırda bu anlayışa göre dersler sürdürülmektedir. Yapılandırmacı yaklaşım olarak lanse edilen bu değişikliklerin temeli derslerin işlenişi ve öğrenciye bakışın farklılaşması şeklinde özetlenebilir. Son olarak ise 2012-2013 yılından itibaren kabul edilen ve kamuda 4+4+4 olarak bilinen değişikliklere değinilecektir.

\section{4+4+4 Eğitim Sistemi}

İlköğretim olarak 8 yll zorunlu olan eğitim kademesinin, öğretim basamaklarının ve sürelerini, aynı zamanda da şekillerini değiştiren ve kamuoyunda " $4+4+4$ " diye bilinen "Yeni Sistem" olarak adlandırılabilecek bir değişiklik yapılmıştır. Değişikliğin yapıldığı sisteme benzer şekilde adı "zorunlu" olsa da, işleyiş bakımından farklılıklar ihtiva etmektedir. Örneğin, öğrencilerin ilk 4 yıldan sonra farklı okulları (örn: imam-hatip ortaokulları) tercih edebilmesi gibi. Bununla beraber ilköğretim kademesini ilk ve orta olmak üzere iki kısımda ele alan bir sistemdir. İlk 4 yıllık süreç ilkokul, ikinci 4 yıllık süreç ise ortaokuldur. MEB'in yayınladığı 2012/20 No'lu Genelge'ye göre özetle;

"İlgili kanun (30/03/2012-6287) ile zorunlu eğitim 12 yıla çıkarılmıştır. Zorunlu eğitim 4 yıl süreli ilkokul, 4 yıl süreli ortaokul ve 4 yıl süreli lise olarak basamaklandırılmıştır. Eylül itibariyle 66 ayını doldurmuş çocuklar ilköğretime alınacaktır. 60-66 ay arası çocuklar için velisinin yazılı isteği ile gelişim yönünden hazır olduğu düşünülenlerin ilkokula devamı sağlanacak, uygun olmayan öğrenciler okul öncesi eğitime yönlendirilecektir. İlkokulu tamamlayan öğrencilere liseden mezun 
olunca diploma verilecektir. YİBO'lar yatılı olarak sadece ortaokul öğrencilerini barındıracaktır. İmkanlar dahilinde okullar ayrıştırılacaktır. Ayrıştırılamayan okulların giriş ve çıkışları farklı olacak şekilde düzenlenecektir. İmam-hatip ortaokulların bağımsız olarak kurulması esas olup, kurulamadığında liseler bünyesinde kurulması sağlanacaktır. Şartlar uygun olursa aynı binada ikili öğretim yapilabilecektir (MEB, 2012)."

Gür ve arkadaşları (2012) yaptıkları çalışmada 4+4+4 olarak bilinen sistemi, okula başlama yaşı, ortaöğretimin yapılandırılması ve SBS'nin kaldırılması, seçmeli dersler ve ders saatleri başlıkları altında değerlendirmişlerdir.

$\mathrm{Bu}$ değişikliği yapan MEB'nın, 4+4+4'ile ilgili sorulan sorulara cevaplar özetle: "Zorunlu eğitimi 12 yıla çıkaran kanunla eğitim sisteminde başlayan yeni dönemin iki temel amacı olan ortalama eğitim süresini yükseltmek, diğeri ise eğitim sisteminin bireylerin ilgi, ihtiyaç ve yeteneklerinin gerektirdiği yönlendirmeyi mümkün kılacak şekilde düzenlenmesidir. Bu değișiklikle 6-6,1 yıl olan ortalama eğitim süresi ve buna bağlı olarak okullaşma oranının arttırılması hedeflenmektedir. Sekiz yıllık zorunlu kesintisiz eğitim yerine, 12 yıllık kademeli zorunlu eğitim esas alınmıştır. Bu on iki yıllık süre, dörder yıllık üç bölümden oluşur. İlk dört yıl ilkokul, ikinci dört yıl ortaokul, üçüncü dört yıl ise lise olarak isimlendirilir. İlkokula başlama yaşı, Eylül ayı itibarı ile önce 60 ayı dolduran şeklinde iken daha sonra Eylül ayı itibariyle 66 ayı dolduran şeklinde değiștirilmiştir. Daha önceki sistemle 31 Aralık baz alınarak 72 ayı dolduran öğrenciler ilkokula alındığı için 2-3 ay fark etmektedir. Bu durum çocuğun fiziki ve ruhi gelișimde olumsuzluk yaratmayacaktır. Her bir bölüm bağımsız oluşabileceği gibi, ihtiyaç olan yerlerde ilkokul+ortaokul, veya ortaokul+lise şeklinde düzenlenebilir. Ortaokulu bitiren birey, ya imam hatip okullarına gidecek ya da diğer liselere gidecektir (MEB, 2012)." şeklinde olmuştur.

Özet olarak 4+4+4 olarak nitelendirilen 12 ylllı zorunlu eğitim, zorunlu ancak kesintisiz değildir. Öğrenci farklı eğitim kademelerini farklı eğitim kurumlarında alabilir. İlkokula Eylül ayı itibarı ile 66 ayını dolduran öğrenciler başlar. Kurumların eğitim süreleri her bir kademe için dört yıldır. Ortaokullarda ve liselerde farklı eğitim kurumları arasında geçiş olabilir.

\section{PISA'da Başarılı Ülkeler ve Eğitim Sistemlerine Özet BakıŞ}

Yapılan değişikliklere bazı araștırmalarda ( Akpınar ve diğerleri 2012; Eğitim-Bir Sen, 2012; Gür ve diğerleri, 2012) dile getirilen bazı olumsuz eleștiriler ve memnun olunmayan bazı hususlardan yola çıkılarak, Dünya'da uygulanmakta olan bazı eğitim modelleri, süreleri ve işleyişleri hakkında genel bir bilgi vermek gerekliliği duyulmuştur. Bu bağlamda PISA'da başarıyı yakalamış ülkelerin uygulamalarından özet olarak tablo aracılığı ile veriler aktarılmıștır.

Tablo 1: Ülkeler, Eğitim Süreleri ve Modelleri

(Bakioğlu, Özcan, Baltacı, Elverici, Göçmen ve diğerleri, 2013)

Elde edilen veriler neticesinde ve yapılan karşılaștırmalar sonucunda; öyle görünmektedir ki, ülkeler eğitim sürelerini ve sistemlerini iç ve dış dinamiklerine veya etkileri neticesinde düzenleyip bir şekilde biçimlendirmişlerdir (Bakioğlu (Ed.) ve diğerleri, 2013). Diğer ülkeler ile karşılaştırmanın kolay yapılabilmesi açısından Türkiye ile ilgili veriler koyu renkli olarak aktarılmıştır. 


\section{AMAÇ}

Bu araştırmada, 4+4+4 eğitim sistemi değişikliği sonrası ortaokul olan 5.sınıflar ve değişiklik sonrası sadece 5.sınıflar ile yaşanan problemlerin, branş öğretmenlerinin görüşleri ışığında genel olarak değerlendirilmesi amaçlanmaktadır.

\section{YÖNTEM}

Araştırma 2013-2014 eğitim öğretim yılında Niğde ili ortaokullarında görev yapan, 5.sınıflara ders veren öğretmenlerle gerçekleştirilmiştir ( $\mathrm{n}=147)$. Araştırmaya katılan öğretmenlerin bir kısmı $(n=34)$ açık uçlu anket formunu doldurmuş, geri kalan kısmı $(n=113)$ ise üçlü likert tipi olan anketi cevaplamıştır.

Araştırmada nitel ve nicel araştırma yöntemlerinin bir arada kullanıldığı karma araştırma deseni tercih edilmiştir. Karma yöntem araștırması, nitel ve nicel yöntemlerle veri toplama, analiz etme ve bütünleştirmeye olanak veren araştırma yöntemidir (Cresswell, Plano Clark, 2007). Tashakkori ve Teddlie (1998) karma yöntem araştırmasını nitel ve nicel yöntemlerle yapılan ve pragmatist felsefeye dayanan araştırma olarak tanımlamıştır. Bu araştırmada da Betimsel analiz, frekans ve yüzde tabloları kullanılmıștır. Öncelikle rastgele örnekleme yoluyla seçilen $(n=34)$ öğretmenlere bir adet açık uçlu soru sorularak konu ile ilgili görüşleri alınmıştır. Bu görüşleri not etmeleri istenmiştir. Daha sonra bu görüşler araştırmacılar tarafından $(n=4)$ incelenerek belirli durumlara yoğunlaşan cevaplar sıralanmıștır. $\mathrm{Bu}$ veriler araștırmacılar tarafından ayrı ayrı incelenmiş ve öğretmenlerin soruya verdikleri cevaplar ve sıraladıkları maddeler kategorize edilmiștir. Öğretmenlerin belirttikleri düşünceler doğrultusunda nicel veri elde etmek amacıyla 38 maddelik bir anket taslağı oluşturulmuştur. Bu maddeler ilk başta araştırmacılar tarafından değerlendirilmiş, soru sayısı fazlalık oluşturan ve birbirine benzer maddelerin elenmesi ile 32'ye düşürülmüştür.

Anket, geliştirilen "Uzman Değerlendirme" formu ile ölçme ve değerlendirme uzmanı, program geliştirme uzmanı, Türkçe öğretimi uzmanı ve sınıf öğretmenliği alan uzmanı tarafından değerlendirilmiștir. Alınan dönütler doğrultusunda anket formu son halini almıștır. Buna göre anket; 30 madde ve 3 alt faktörden oluşmaktadır. Bu faktörler; öğretmen kaynaklı sorunlar, öğrenci kaynaklı sorunlar ve diğer etkenler şeklinde adlandırılmıştır. Anket yine rastgele örnekleme yoluyla seçilen ( $\mathrm{n}=113)$ branş öğretmenlerine uygulanmıştır.

Anketin toplam Cronbach's Alpha katsayısı $0.86(\alpha=.862)$, alt faktörlerinki ise; öğrenci faktörü için $0.80(\alpha=.798)$, öğretmen faktörü için $0.72(\alpha=.720)$, diğerleri faktörü için $0.71(\alpha=.713)$, olarak hesaplanmıștır.

\section{BULGULAR}

Öğrenci Faktörü: İlk 11 tablo öğrenci boyutuyla ilgilidir.

Tablo 2: "Yaşları üst sınıf öğrencileriyle aynı ortamda olmaya uygun değildir" Maddesine Ait Yüzde ve Frekanslar

\begin{tabular}{lll}
\hline \multicolumn{1}{c}{ Görüssler } & Frekans (f) & Yüzde (\%) \\
\hline Katılmıyorum & 26 & 23 \\
Kararsızım & 16 & 14.2 \\
Katılıyorum & 71 & 62.8 \\
Toplam & 113 & 100 \\
\hline
\end{tabular}

Tablo 2'ye göre araştırmaya katılan öğretmenlerin \%62.8'i beşinci sınıf öğrencilerinin yaşlarının üst sınıf öğrencilerle aynı ortamda bulunmaya uygun olmadığını belirtmiştir. Görüldüğü gibi araştırmaya katılan öğretmenlerin büyük çoğunluğu beşinci sınıf öğrencileri ile diğer ortaokul öğrencilerinin aynı ortamda bulunmaması gerektiğini söylemiştir. 


\section{Öğretmen on beş}

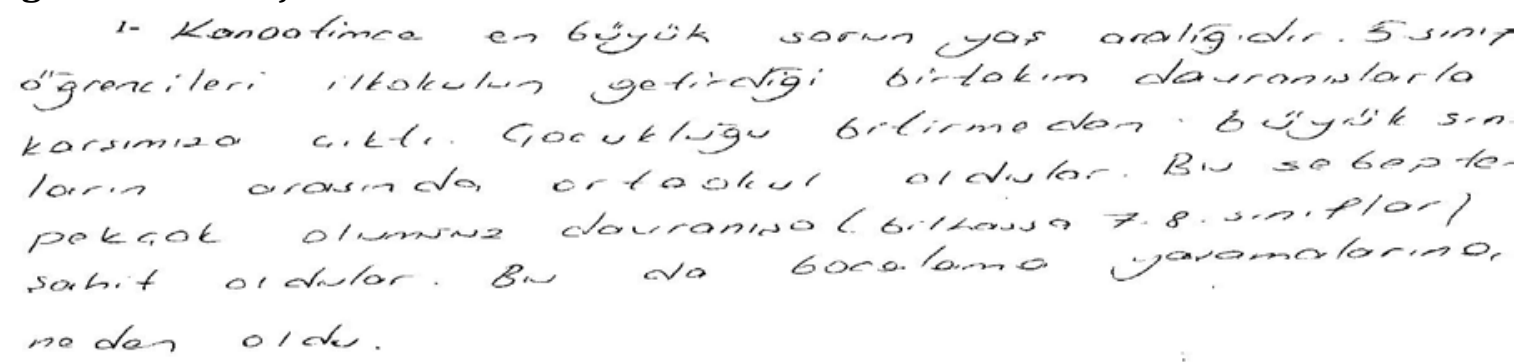

\section{Öğretmen otuz}

1- 5.sinf ogmencileri yoslarinin vïciü olmasi sebebiyle artackula adopte olmakta süalük cetemektedirler. Brans oggretmenterire ythelt. tipler? sorular, ders ve ders disinda sergilechleen dauranislarla tek bir sinf gigretreninin ilgi ve seflatine Thtiyas duydudelasini belti etroktedirler.

Tablo 3: "Birden fazla öğretmene alıșmakta zorlanmaktadırlar." Maddesine Ait Yüzde ve Frekanslar

\begin{tabular}{cll}
\hline Görüssler & Frekans (f) & Yüzde (\%) \\
\hline Katılmıyorum & 28 & 24.8 \\
Kararsızım & 20 & 17.7 \\
Katılıyorum & 65 & 57.5 \\
Toplam & 113 & 100 \\
\hline
\end{tabular}

Tablo 3'de öğretmenlerin \%57.5'i beşinci sınıf öğrencilerin birden fazla öğretmene alışmakta zorlandığını belirtmiştir. Tablodan da anlaşılacağı gibi araștırmaya katılan öğretmenlerin yarıdan fazlası bu öğrencilerin birden ortaokul oldukları için öğretmen sayısındaki artışa adapte olamadığını söylemiştir.

\section{Öğretmen beș}

\section{1- Tek sgaretmene alisik olduldarindom uyum prob- lemi yasiyorlar.}

Tablo 4: "Ergenlik döneminde olan büyük öğrenciler ile uyum sağlayamamaktadırlar." Maddesine Ait Yüzde ve Frekanslar

\begin{tabular}{cll}
\hline Görüşler & Frekans (f) & Yüzde (\%) \\
\hline Katılmıyorum & 17 & 15 \\
Kararsızım & 13 & 11.5 \\
Katılıyorum & 83 & 73.5 \\
Toplam & 113 & 100 \\
\hline
\end{tabular}

Tablo 4'te öğretmenlerin \%73.5'i beşinci sınıf öğrencilerinin ergenlik döneminde olan büyük öğrenciler ile uyum sağlayamadığını düşünmektedir. Tablodan da anlaşılacağı gibi öğretmenlerin yarıdan fazlası beşinci sınıf öğrencileri ile ergenlik dönemindeki öğrencilerin uyum sağlayamadığını söylemiştir.

\section{Öğretmen yirmi yedi}

$$
\begin{aligned}
& \text { 3-küaïl yastakir bs j’grencilesin, ergenlik erresine } \\
& \text { girmis jogrencilerle uyumu pel koby degil. }
\end{aligned}
$$


Tablo 5: “Henüz üst sınıflardaki öğrenciler gibi sorumluluk alamamaktadırlar.” Maddesine Ait Yüzde ve Frekanslar

\begin{tabular}{cll}
\hline Görüșler & Frekans (f) & Yüzde (\%) \\
\hline Katılmıyorum & 32 & 28.3 \\
Kararsızım & 21 & 18.6 \\
Katılıyorum & 60 & 53.1 \\
Toplam & 113 & 100 \\
\hline
\end{tabular}

Tablo 5'te öğretmenlerin \%53.1'i beșinci sınıf öğrencilerinin henüz üst sınıflardaki öğrenciler gibi sorumluluk alamadığını belirtmiştir. Yaşları küçük olan bu öğrenciler diğer ortaokul öğrencileri ile kıyaslandığında onlar kadar sorumluluk alamamaktadır. Tabloya baktığımızda da öğretmenlerin yarıdan fazlası böyle düşünmektedir.

\section{Öğretmen iki}

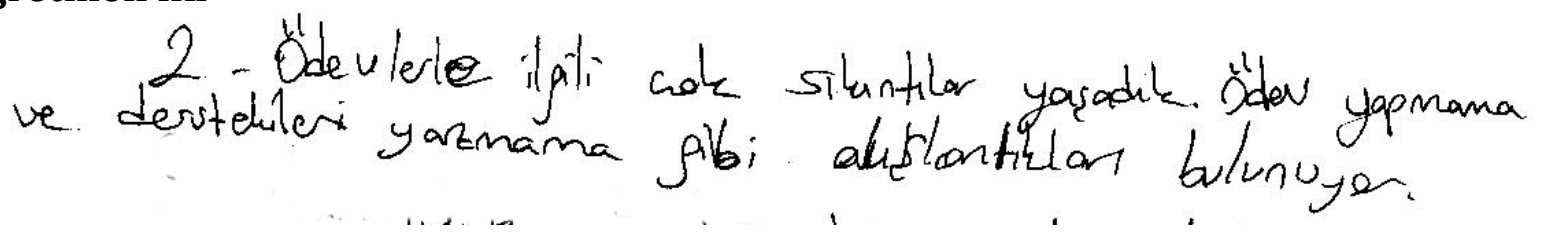

\section{Öğretmen yirmi dokuz}

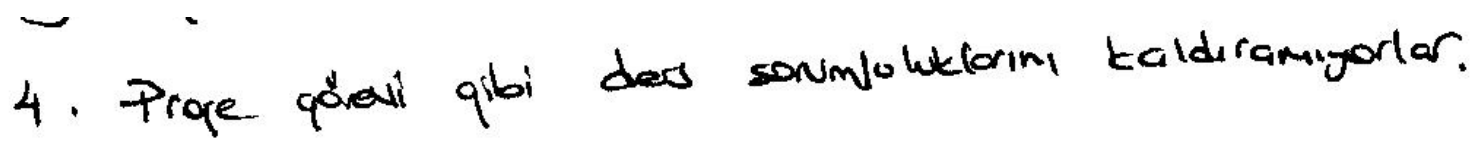

Tablo 6: "Derslerde odaklanma, dikkat ve dinleme sorunları yaşamaktadırlar." Maddesine Ait Yüzde ve Frekanslar

\begin{tabular}{cll}
\hline Görüșler & Frekans (f) & Yüzde (\%) \\
\hline Katılmıyorum & 30 & 26.5 \\
Kararsızım & 26 & 23 \\
Katılıyorum & 57 & 50.4 \\
Toplam & 113 & 100 \\
\hline
\end{tabular}

Tablo 6'e göre öğretmenleri \%50.4'ü bu öğrencilerin derslerde odaklanma, dikkat ve dinleme sorunları yaşadığını belirtmiştir.

\section{Öğretmen üç}

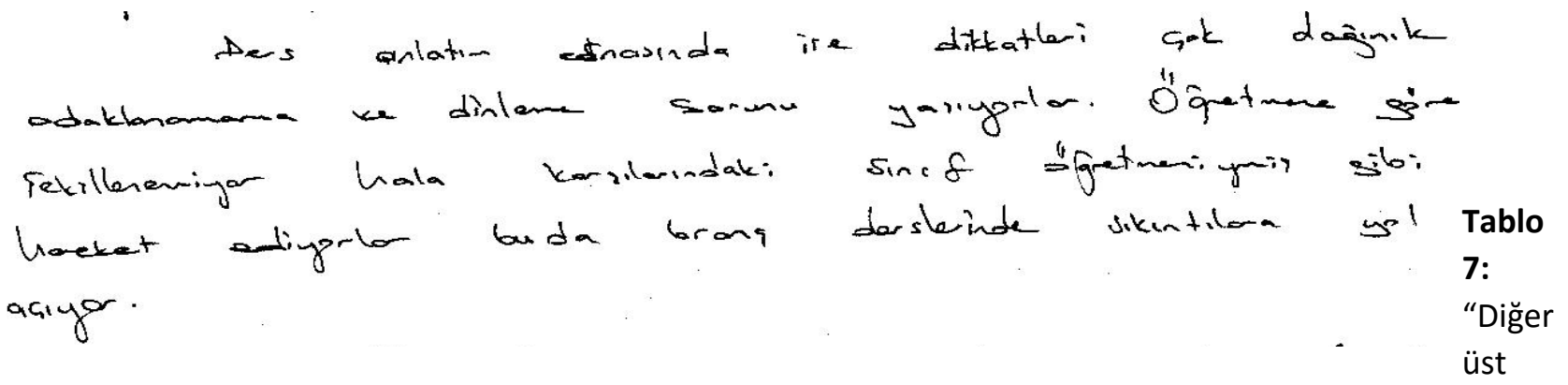

sınıf öğrencilere göre çocuksu davranışları fazladır." Maddesine Ait Yüzde ve Frekanslar

\begin{tabular}{cll}
\hline Görüşler & Frekans (f) & Yüzde (\%) \\
\hline Katılmıyorum & 6 & 5.3 \\
Kararsızım & 12 & 10.6 \\
Katıllyorum & 95 & 84.1 \\
Toplam & 113 & 100 \\
\hline
\end{tabular}


Tablo 7'ye göre öğretmenlerin \%84.1'i beşinci sınıf öğrencilerinin diğer üst sınıf öğrencilere öre çocuksu davranışlarının fazla olduğunu belirtmiștir. Tabloda da görüldügü gibi araştırmaya katılan öğretmenlerin neredeyse tamamı bu öğrencilerin diğer öğrencilere göre daha çocuksu olduğunu söylemiştir.

\section{Öğretmen altı}

$$
\begin{aligned}
& \text { 3- Ontaokuilu Dldugunun farkina laramayan bjgenciler } \\
& \text { daunanistarinda da cocukita illcokul aligkanlikbrini } \\
& \text { südürmektedir. Ornejin sinfta yeme iame, apjlama }
\end{aligned}
$$

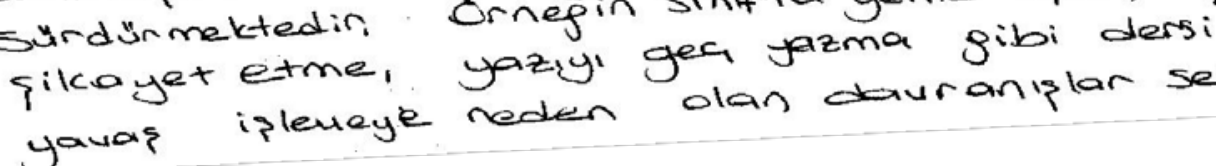

$$
\begin{aligned}
& \text { olan duuranizlar sergilemekteris. }
\end{aligned}
$$

Tablo 8 : "Beșinci sınıftaki yoğun tempodan sıkılmaktadırlar." Maddesine Ait Yüzde ve Frekanslar

\begin{tabular}{cll}
\hline Görüşler & Frekans (f) & Yüzde (\%) \\
\hline Katılmıyorum & 28 & 24.8 \\
Kararsızım & 22 & 19.5 \\
Katılıyorum & 63 & 55.8 \\
Toplam & 113 & 100 \\
\hline
\end{tabular}

Tablo 8'de öğretmenlerin \%55.8'i öğrencilerin beșinci sınıftaki yoğun tempodan sıkıldığını belirtmiştir. Araştırmaya katılan öğrencilerin yarında fazlası ortaokula küçük yașta ve soyut işlemler dönemine tamamen geçemeyen öğrencilerin sınıf içindeki yoğun tempodan etkilendiğini söylemiştir.

\section{Öğretmen on dört}

3 Sabah ilk saatler erken kalkmonin rehavetiyle odaklanamyorlar, bahualt, bile yapmaron geliyorkor, derslerce gi2li giali birseyler yerne dendinde oluyorlar. Son soctlerde yorgulukton motive olamiyorkor. Tereffüsler kisa oldfundon intigaslorini vetistiremiportar. Haligle verimli olbbildikleri süre 3 . ve 4 . ders saatkeri ike sinirli kdiyor.

[4] 5. sinifta bunca kasturmacaga birden atilon garencilerin afon. ligju 6. sinifta buklumlik, bosvermislik durumlor sergiligor
notlorinda disüs yasigor.

Tablo 9: "Henüz somut düşünme döneminden çıkamamışlardır." Maddesine Ait Yüzde ve Frekanslar

\begin{tabular}{cll}
\hline Görüşler & Frekans (f) & Yüzde (\%) \\
\hline Katılmıyorum & 17 & 15 \\
Kararsızım & 24 & 21.2 \\
Katılıyorum & 72 & 63.7 \\
Toplam & 113 & 100 \\
\hline
\end{tabular}

Tablo 9'a göre öğretmenlerin \%63.7'si beşinci sınıf öğrencilerinin somut işlemler döneminde çıkamadığını belirtmiştir. Tabloda da görüldüğü gibi öğretmenlerin yarıdan fazlası bu öğrencilerin hala somut işlemler döneminden çıkamadı̆̆ını söylemiştir. 


\section{Öğretmen yirmi üç}

V. Isin sis zihinsel qelisimleri tam olmadigindan, somut dirinime

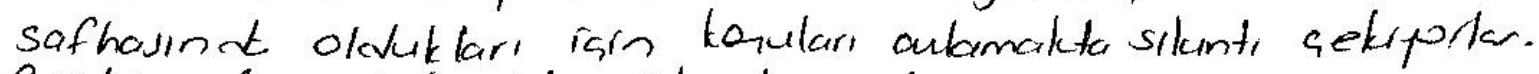
Briler de anlatmakta sitint! Gelcryorun.

Tablo 10: "Özgüven eksikliği hissetmektedirler." Maddesine Ait Yüzde ve Frekanslar

\begin{tabular}{llll}
\hline Ölçekler & & Frekans (F) & Yüzde (\%) \\
\hline & Katılmıyorum & 47 & 41.6 \\
& Kararsızım & 34 & 30.1 \\
& Katılıyorum & 32 & 28.3 \\
& Toplam & 113 & 100.0 \\
\hline
\end{tabular}

Tablo 10'da öğretmenlerin \%41.6'sı beşinci sınıf öğrencilerinin özgüven eksikliği hissetmediğini belirtmiştir.

Tablo 11: "Bașarısızlık Korkusu Yașamaktadırlar." Maddesine Ait Yüzde ve Frekanslar

\begin{tabular}{cll}
\hline Görüşler & Frekans (f) & Yüzde (\%) \\
\hline Katılmıyorum & 51 & 45.1 \\
Kararsızım & 31 & 27.4 \\
Katılıyorum & 31 & 27.4 \\
Toplam & 113 & 100 \\
\hline
\end{tabular}

Tablo 11'de araştırmaya katılan öğretmenlerin \%45.1'i beşinci sınıf öğrencilerinin başarısızlık korkusu yaşamadığını belirtmiştir.

Tablo 12: "Kendilerini hala ilkokulda gibi hissetmektedirler." Maddesine Ait Yüzde ve Frekanslar

\begin{tabular}{cll}
\hline Görüşler & Frekans (f) & Yüzde (\%) \\
\hline Katılmıyorum & 12 & 10.6 \\
Kararsızım & 14 & 12.4 \\
Katılıyorum & 87 & 77.0 \\
Toplam & 113 & 100 \\
\hline
\end{tabular}

Tablo 12'de öğretmenlerin \%77'si beşinci sınıf öğrencilerinin kendilerini hala ilkokulda gibi hissettiğini belirtmiştir. Tablodan da görüldüğü gibi araştırmaya katılan öğretmenlerin büyük çoğunluğu 4+4+4 eğitim sistemi ile beşinci sinıf öğrencilerinin ortaokul için yeterli olgunluğa erișemediklerini söylemektedir.

\section{Öğretmen yedi}

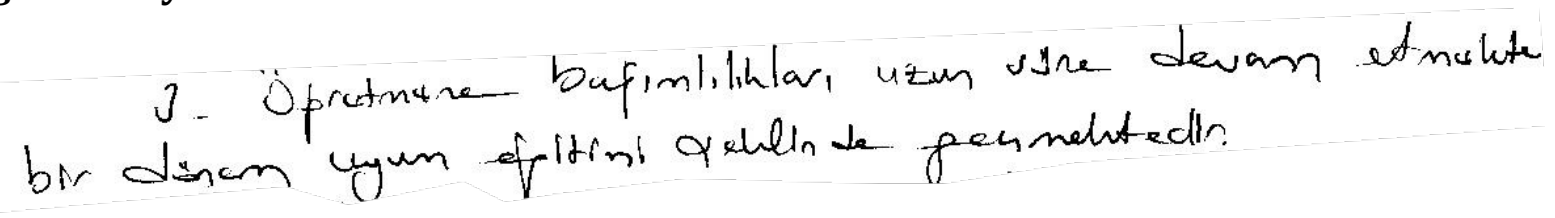

Öğretmen Faktörü: 12.-24. Tablolar öğretmen faktörü ile ilgilidir.

Tablo 13: "Öğrencilerin şefkat, ilgi gibi ihtiyaçlarına yeterince cevap veremiyorum." Maddesine Ait Yüzde ve Frekanslar

\begin{tabular}{cll}
\hline Görüşler & Frekans (f) & Yüzde (\%) \\
\hline Katılmıyorum & 56 & 49.6 \\
Kararsızım & 31 & 27.4 \\
Katılıyorum & 26 & 23 \\
Toplam & 113 & 100 \\
\hline
\end{tabular}


Tablo 13'de araştırmaya katılan öğretmenlerin \%49.6'sı kendilerini beşinci sınıf öğrencilerinin şefkat, ilgi gibi ihtiyaçlarına yeterince cevap verebildiğini düşünürken, \%50.3'ü bu konuda kararsız kalmıștır ya da beklentilere cevap veremediğini düşünmüştür.

\section{Öğretmen yirmi yedi}

$$
\begin{aligned}
& \text { 4- Ve brans s'gretmenteri darak sigiencilerle cok } \\
& \text { fazla birebir ilgilermemiz mismkin olmugor } \\
& \text { fakat 5. sinif oggrencileri } 4 \text { yll teke itek ilgige } \\
& \text { alistiklari iain bizden de bo sekilde beklentileri } \\
& \text { oluyar, bu durum yabonalik hissetrelerine sebes } \\
& \text { olyyor. }
\end{aligned}
$$

Tablo 14: “Öğrencilerin seviyesine inmekte zorlanıyorum.” Maddesine Ait Yüzde ve Frekanslar

\begin{tabular}{cll}
\hline Görüssler & Frekans (f) & Yüzde (\%) \\
\hline Katılmıyorum & 72 & 63.7 \\
Kararsızım & 21 & 18.6 \\
Katılıyorum & 19 & 16.8 \\
Toplam & 113 & 100 \\
\hline
\end{tabular}

Tablo 14'te öğretmenlerin \%63.7'si öğrencilerin seviyelerine inmekte zorlandıklarını belirtmiştir. Daha çok soyut işlemler dönemindeki öğrenciler için eğitim alan branș öğretmenleri değişen eğitim sistemi ile beşinci sınıf öğrencilerinin seviyesine inmekte zorlandıklarını söylemiştir.

\section{Öğretmen sekiz}

1- Ogrenciler ilkokulu bitirip de onbookulda obluklarinen pele farkinda olmadiklarindan derse uyum soglamakta sonan yasamat. Aalar. Bu uyumu aynen ben de yoramattaym. Kisocase olgun lasmanus kagnallanon sorunlar yosonmaktadir.

\section{Öğretmen on bir}

1. Ëgrencilein sevigateine inmakte sikinti yojodim. CDersontati

\section{Öğretmen On}

4-Hazrliksiz yakalandiğmiz bu sistemde gärencikrin yas yasadim. Ayrica 5. siniflar isin yygulanan once 8. saat 7. saat youmasi ögrenciler icin verimsiz 
Tablo 15 : “Öğrencilerin bizlere yönelik “öğretmen algıları” olumsuz yönde gelişmektedir.” Maddesine Ait Yüzde ve Frekanslar

\begin{tabular}{|c|c|c|c|c|}
\hline \multirow[t]{5}{*}{ Görüşler } & \multirow[t]{5}{*}{ Frekans (f) } & \multicolumn{2}{|l|}{ Yüzde (\%) } & \multirow[b]{2}{*}{56.6} \\
\hline & & Katılmıyorum & 64 & \\
\hline & & Kararsızım & 35 & 31.0 \\
\hline & & Katılıyorum & 14 & 12.4 \\
\hline & & Toplam & 113 & 100 \\
\hline
\end{tabular}

Tablo 15'te öğretmenlerin \%56.6'sı öğrencilerin kendilerine yönelik algılarının olumsuz yönde geliştiğini belirtmiştir. Tabloda da görüldügü gibi araştırmaya katılan öğretmenlerin yarıdan fazlası küçük yaşta ortaokula geçen beşinci sınıf öğrencilerinin kendilerine yönelik algılarının olumsuz yönde geliştiğini söylemektedir.

Öğretmen on dört

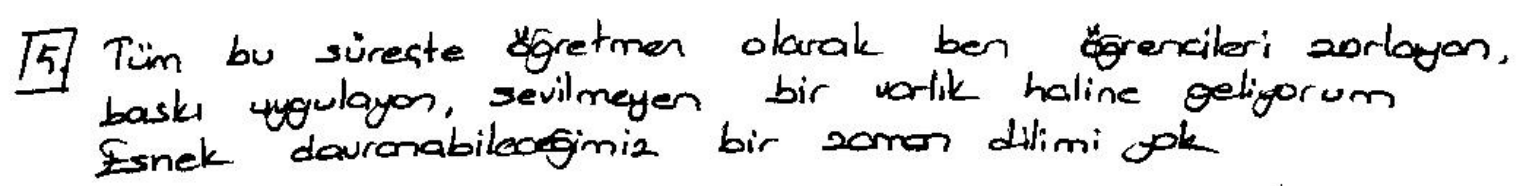

Tablo 16: "Sınıflarda branș öğretmeni açığı yașanmaktadır." Maddesine Ait Yüzde ve Frekanslar

\begin{tabular}{llll}
\hline Ölçekler & & Frekans (f) & Yüzde (\%) \\
\hline & Katılmıyorum & 60 & 53.1 \\
& Kararsızım & 17 & 15 \\
Katılıyorum & 36 & 31.9 \\
Toplam & 113 & 100 \\
\hline
\end{tabular}

Tablo 16'da öğretmenlerin \%53,1'i sınıflarda branş öğretmeni açı̆̆ı yaşanmadığını belirtmiştir.

Tablo 17: "Sınıflarda ders sayımız arttığı için verimli olamıyorum." Maddesine Ait Yüzde ve Frekanslar

\begin{tabular}{cll}
\hline Görüssler & Frekans (f) & Yüzde (\%) \\
\hline Katılmıyorum & 70 & 61.9 \\
Kararsızım & 17 & 15 \\
Katılıyorum & 26 & 23 \\
Toplam & 113 & 100 \\
\hline
\end{tabular}

Tablo 17'de öğretmenlerin \% 61.9'u kendilerini, ders sayısı arttığı halde verimli olabildiğini belirtmiştir.

\section{Öğretmen sekiz}

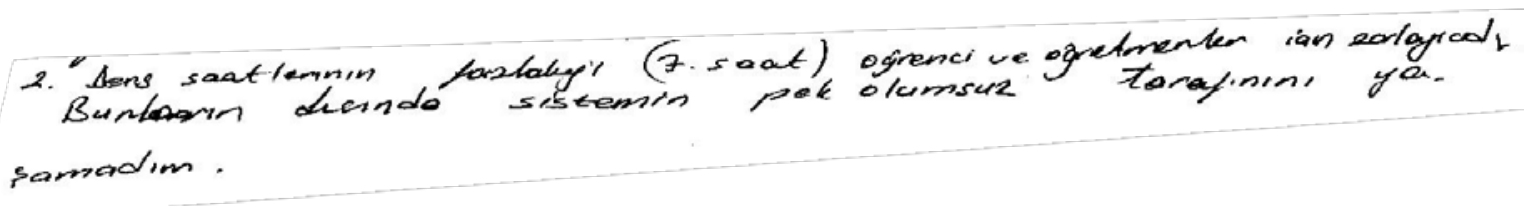

\section{Öğretmen yirmi bir}

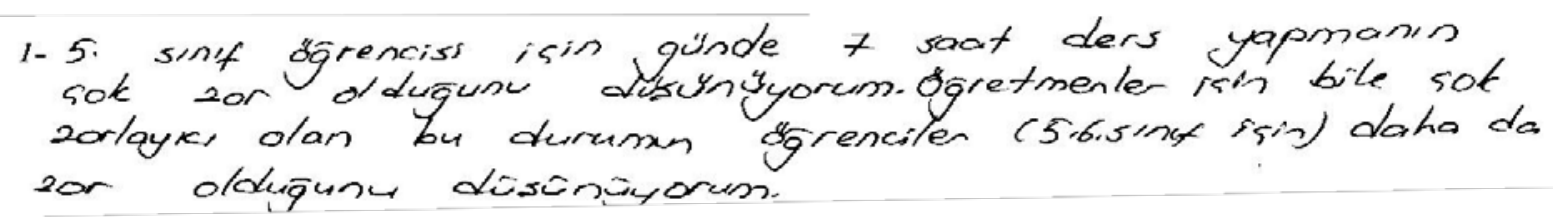


Tablo 18: "Öğrencilerle sınıf içinde disiplin sorunları yaşıyorum." Maddesine Ait Yüzde ve Frekanslar

\begin{tabular}{lll}
\hline Görüșler & Frekans (f) & Yüzde (\%) \\
\hline Katılmıyorum & 57 & 50.4 \\
Kararsızım & 25 & 22.1 \\
Katıllyorum & 31 & 27.4 \\
Toplam & 113 & 100 \\
\hline
\end{tabular}

Tablo 18'de öğretmenlerin \%50.4'ü sınıf içinde disiplin sorunları yaşamadığını belirmiştir. Fakat araştırmaya katılan öğretmenlerin \%49.5'i aynı düşünmemektedir. Arada neredeyse yarı yarıya bir fark vardır.

\section{Öğretmen altı}

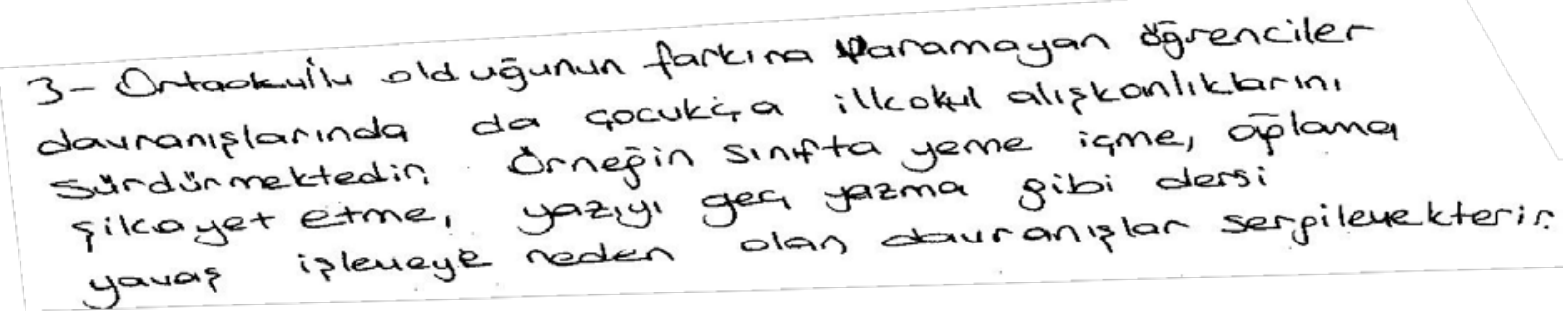

Tablo 19: "Sınıflarda öğrencilerle istenmeyen davranışlarla baş etmede sıkıntı yaşıyorum." Maddesine Ait Yüzde ve Frekanslar

\begin{tabular}{lll}
\hline Görüssler & Frekans (f) & Yüzde (\%) \\
\hline Katılmıyorum & 59 & 52.2 \\
Kararsızım & 27 & 23.9 \\
Katılıyorum & 27 & 23.9 \\
Toplam & 113 & 100 \\
\hline
\end{tabular}

Tablo 19'da öğretmenlerin \%52.2'si beşinci sınıflarda öğrencilerle istenmeyen davranışlarla sıkıntı yaşamadığını belirtirken araștırmaya katılan öğretmenlerin \%47.8'i bu konuya katıldığını ya da katıldığını söylemiştir.

\section{Öğretmen on iki}

$$
\text { 4. Yani genel darale sirif otoritesinde problanler }
$$

Tablo 20: "Sınıflarda öğrencilere yeterince sabırlı ve anlayışlı davranamıyorum." Maddesine Ait Yüzde ve Frekanslar

\begin{tabular}{lll}
\hline Görüşler & Frekans (f) & Yüzde (\%) \\
\hline Katılmıyorum & 64 & 56.6 \\
Kararsızım & 28 & 24.8 \\
Katılıyorum & 21 & 18.6 \\
Toplam & 113 & 100 \\
\hline
\end{tabular}

Tablo 20'de öğretmenlerin \%56.6'sı sınıfta öğrencilere yeterince sabırlı ve anlayışlı davrandığını belirtmiştir. 


\section{Öğretmen on dört}

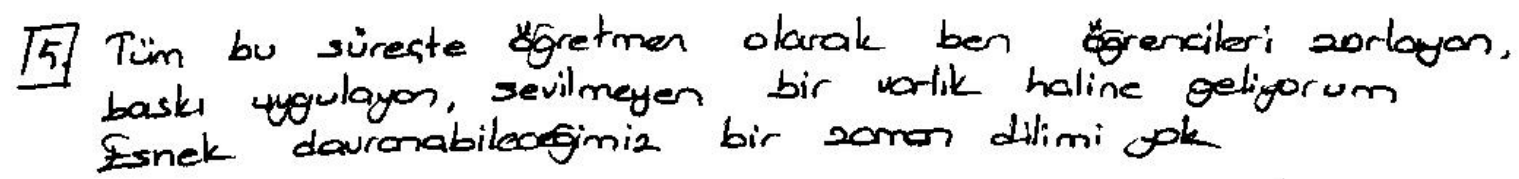

Tablo 21: "Sinıfların derslerine girerken isteksizlik yașıyorum." Maddesine Ait Yüzde ve Frekanslar

\begin{tabular}{lll}
\hline Görüșler & Frekans (f) & Yüzde (\%) \\
\hline Katılmıyorum & 69 & 61.1 \\
Kararsızım & 25 & 22.1 \\
Katılıyorum & 19 & 16.8 \\
Toplam & 113 & 100 \\
\hline
\end{tabular}

Tablo 21'e göre öğretmenlerin \%61'i beşinci sınıfların derslerine girerken isteksizlik yaşamadığını belirtmiştir. Bu gibi tutum özelliklerinin ölçümünde gözlem vb. derinlemesine yapılacak araştırmalara ihtiyaç olsa da, öğretmenlerin verdiği cevaba bakarak çoğunluğun derslere istekle girdiği söylenebilir.

Tablo 22: "Öğrenciler öğretmenler tarafindan birebir ilgi göremeyince okulda yabancllı hissetmektedirler." Maddesine Ait Yüzde ve Frekanslar

\begin{tabular}{lll}
\hline Görüssler & Frekans (f) & Yüzde (\%) \\
\hline Katılmıyorum & 37 & 32.7 \\
Kararsızım & 35 & 31.0 \\
Katıllyorum & 41 & 36.3 \\
Toplam & 113 & 100 \\
\hline
\end{tabular}

Tablo 22'de öğretmenlerin \%36.3'ü öğrencilerin öğretmenler tarafından birebir ilgi göremeyince okulda yabancıllk çektiğini belirtmiştir.

\section{Öğretmen otuz}

1- 5.sinf dgiencilen yaslarinin kïciü olmasi sebebiyle ortackula adapte olmakta süaluk ceternektedirler. Brans g̈gretmenterire ÿhelt. tikberi sorular, ders ve ders disinda sargilechklen davranislarla tek bir sinff ggretmeninin ilgi ve sefkatine ihtiyac duyduklarini bell etrvektedirler.

Tablo 23: "Öğrenciler üst sınıf öğrencilere göre fazla ayrıntı sormaktadırlar." Maddesine Ait Yüzde ve Frekanslar

\begin{tabular}{lll}
\hline Görüşler & Frekans (f) & Yüzde (\%) \\
\hline Katılmıyorum & 29 & 25.7 \\
Kararsızım & 22 & 19.5 \\
Katılıyorum & 62 & 54.9 \\
Toplam & 113 & 100,0 \\
\hline
\end{tabular}

Tablo 22'de öğretmenlerin \%54.9'u beşinci sınıf öğrencilerinin üst sınıf öğrencilerine göre daha fazla ayrıntı sorduğunu belirmiştir. Araștırmaya katılan öğretmenlerin yarıdan fazlası bu öğrencilerin daha ayrıntıcı olduğunu söylemiștir. 
Tablo 24 : "Öğrencileri değerlendirmede zorluk yașıyorum." Maddesine Ait Yüzde ve Frekanslar

\begin{tabular}{lll}
\hline Görüsşler & Frekans (f) & Yüzde (\%) \\
\hline Katılmıyorum & 71 & 62.8 \\
Kararsızım & 26 & 23 \\
Katılıyorum & 16 & 14.2 \\
Toplam & 113 & 100 \\
\hline
\end{tabular}

Tablo 24'te öğretmenlerin \%62.8'i öğrencileri değerlendirmekte zorluk yaşamadığını belirtmiştir.

Tablo 25: "Öğrencilerin ilk beş yıllarını sınıf öğretmeni ile geçirmelerini daha uygun buluyorum." Maddesine Ait Yüzde ve Frekanslar

\begin{tabular}{lll}
\hline Görüșler & Frekans (f) & Yüzde (\%) \\
\hline Katılmıyorum & & \\
Kararsızım & 30 & 26.5 \\
Katılıyorum & 14 & 12.4 \\
Toplam & 69 & 61.1 \\
\hline
\end{tabular}

Tablo 25'te öğretmenlerin \%61.1'i öğrencilerin ilk beş yılını sınıf öğretmeni ile geçirmelerini daha uygun bulduğunu belirtmiştir. Yine görüldüğü gibi öğretmenlerin yarısından fazlası beșinci sınıf öğrencilerinin sınıf öğretmeni ile daha başarılı olacağına inanmaktadır.

\section{Diğer Faktörler: Beşinci Sınıflara/Sınıfların...}

Tablo 26: "Yedi veya sekiz ders fazla gelmektedir." Maddesine Ait Yüzde ve Frekanslar

\begin{tabular}{lll}
\hline Görüșler & Frekans (f) & Yüzde (\%) \\
\hline Katılmıyorum & 17 & 15 \\
Kararsızım & 12 & 10.6 \\
Katılıyorum & 84 & 74.3 \\
Toplam & 113 & 100 \\
\hline
\end{tabular}

Tablo 26'ya göre araștırmaya katılan öğretmenlerin \%74.3'ü ile 84'ü beșinci sınıflara yedi veya sekiz dersin fazla geldiğini belirtmiştir.

\section{Öğretmen Bir}

3- Ginde 7 saat ders islemele üst sinflarda cole olmasa da 5. sinflarda sikilma, yorguhluk ve dersten lasma gibi sonualor ortaya citharabiliyor.

\section{Öğretmen yedi}

$$
\text { 4. } 7 \text { (Yedi) dars saati } 5 . \sin 18 \text { uprundiure afpir felfor. }
$$

\section{Öğretmen on yedi}

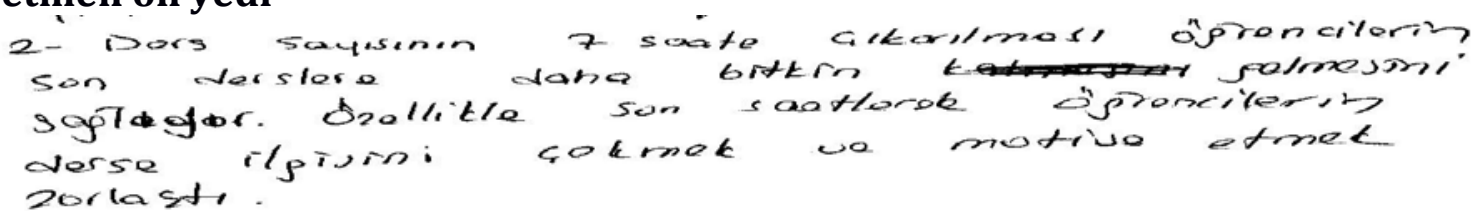




\section{Öğretmen on dokuz}

$$
\text { - Ogrencile 7. sante sol istelsir giriyo-lor }
$$

Tablo 27: "Ders konuları öğrencilerin kavrama düzeyine uygun değildir." Maddesine Ait Yüzde ve Frekanslar

\begin{tabular}{lll}
\hline Görüşler & Frekans (f) & Yüzde (\%) \\
\hline Katılmıyorum & 52 & 46 \\
Kararsızım & 29 & 25.7 \\
Katıllyorum & 32 & 28.3 \\
Toplam & 113 & 100 \\
\hline
\end{tabular}

Tablo 27'de öğretmenlerin \%46'sı ile 52'si ders konularının öğrencilerin kavrama düzeyine uygun olduğunu belirtmiştir. Fakat \%54'ü bu konuda kararsız kalmıștır ya da uygun olmadığını söylemiştir. Bu oran manidardır.

\section{Öğretmen on dokuz}

$$
\begin{aligned}
& \text { MATEMATIK DERSI } \\
& \text { 1- 2012-2013 yilinda okutulan 5. simf mifiedat, su an 2013-2011 } \\
& \text { yil. Sisinf mifredatindon dyodaha iyiydi: Su on okutalan } \\
& \text { 5. sinif mifredatinin iai cok farla busaltrimis. yoni mifredatt } \\
& \text { Gok az hazanim vor. }
\end{aligned}
$$

Tablo 28: "Ders kitaplarında soyut kavramlar fazladır." Maddesine Ait Yüzde ve Frekanslar

\begin{tabular}{lll}
\hline Görüssler & Frekans (f) & Yüzde (\%) \\
\hline Katılmıyorum & 41 & 36.3 \\
Kararsızım & 26 & 23 \\
Katılıyorum & 46 & 40.7 \\
Toplam & 113 & 100 \\
\hline
\end{tabular}

Tablo 28'de öğretmenlerin \%40.7'si beşinci sınıf ders kitaplarında soyut kavramların fazla olduğunu belirtmiştir. Araştırmaya katılan öğretmenlerin neredeyse yarısı beşinci sınıf kitaplarında soyut kavramların fazla olduğunu söylemiştir.

\section{Öğretmen yirmi altı}

1-Derskitaplarinin yetersizligi dersteki enbugut soran oldaḡpu

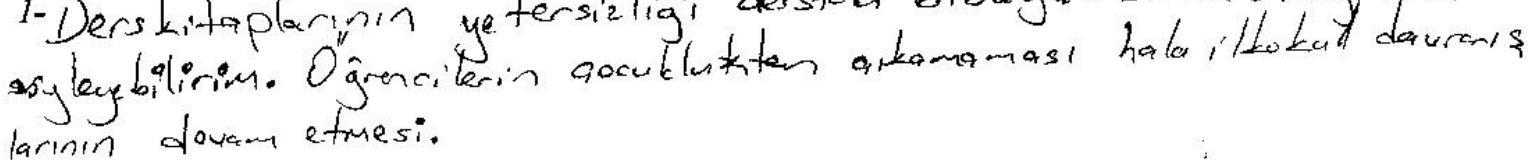

\section{Öğretmen on üç}

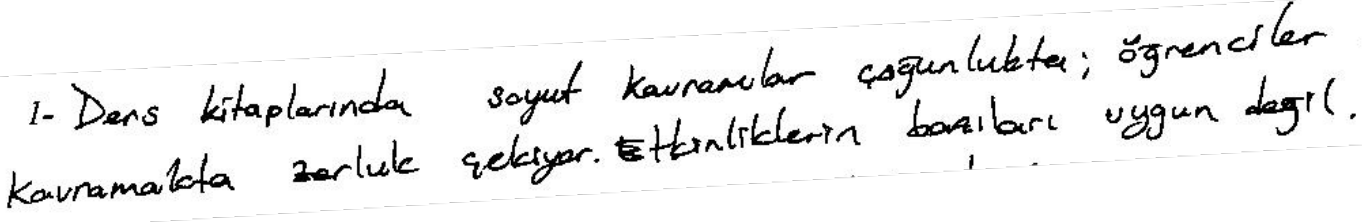




\section{Öğretmen on sekiz}

$$
\begin{aligned}
& \text { 2- Ders kitaplar cocubbara ejonelik degildi. Kaynak } \\
& \text { ritaplar (ögretmen ilavuz ritabe) uygun degil Ne } \\
& \text { onbatacoginin klaverda belli degil Klaver kitaplordan } \\
& \text { ders isleneminor. } \\
& \text { 3. Dess ritaplorinda yer alan ettinlibleri yourken } \\
& \text { cocublar sikilyor. Ettinliblerin daha ejglencti ve } \\
& \text { ögretici olmasi gerebiyor. }
\end{aligned}
$$

Tablo 29: "Giriş ve çıkış saatleri öğrencilerin yaşlarına uygun değildir." Maddesine Ait Yüzde ve Frekanslar

\begin{tabular}{lll}
\hline Görüşler & Frekans (f) & Yüzde (\%) \\
\hline Katılmıyorum & 24 & 21.2 \\
Kararsızım & 13 & 11.5 \\
Katılıyorum & 76 & 67.3 \\
Toplam & 113 & 100 \\
\hline
\end{tabular}

Tablo 29'da öğretmenlerin \%67.3'ü ders giriş ve çıkış saatlerinin beșinci sınıf öğrencilerinin yaşlarına uygun olmadığını düşünmektedir. Tabloda da görüldüğü gibi öğretmenlerin yarıdan fazlası ders saatlerini uygun bulmamaktadır. Özellikle ilkokul ve ortaokul binası ayrılmayan kurumlarda ders saatleri arttığı öğrenciler erken girip geç çıkmaktadır. Bu durum hem beşinci sınıf öğrencileri için hem de bu durumdan etkilenen ilkokul öğrencileri için uygun olmayan saatlerde ders işleme zorunluluğu getirmiştir.

\section{Öğretmen on dört}

3 Sabah ilk saatler erken kalkmonin rehavetiyle odaklanamyorlar, bahualt, bile yapmarton geliyartor, derslerde giali giali birseyler yeme dendinde oluyorlar. Son soctlerde yorgunukton motive olamiyorkar. Tereffüsler kisa oldfundon ihtifxlorin getistiremiportar. Halíle verimli obbildikleri süre 3 . ve 4 . ders saatteri ik sinirli kdiyor.

Tablo 30: “Öğrenciler hızlı acıktıkları için motivasyon düşmektedir." Maddesine Ait Yüzde ve Frekanslar

\begin{tabular}{lll}
\hline Görüșler & Frekans (f) & Yüzde (\%) \\
\hline Katılmıyorum & 17 & 15 \\
Kararsızım & 16 & 14.2 \\
Katılıyorum & 80 & 70.8 \\
Toplam & 113 & 100 \\
\hline
\end{tabular}

Tablo 30'da öğretmenlerin \%70.8'i öğrencilerin hızlı acıktıkları için motivasyonunun düştügünü belirtmiştir. Yaşları küçük olan beşinci sınıf öğrencilerinin açlıklarını bastıramadıkları için ders içi motivasyonu düşmüştür. Tabloda da görüldüğü gibi öğretmenleri büyük çoğunluğu böyle düşünmektedir. 


\section{Öğretmen on sekiz}

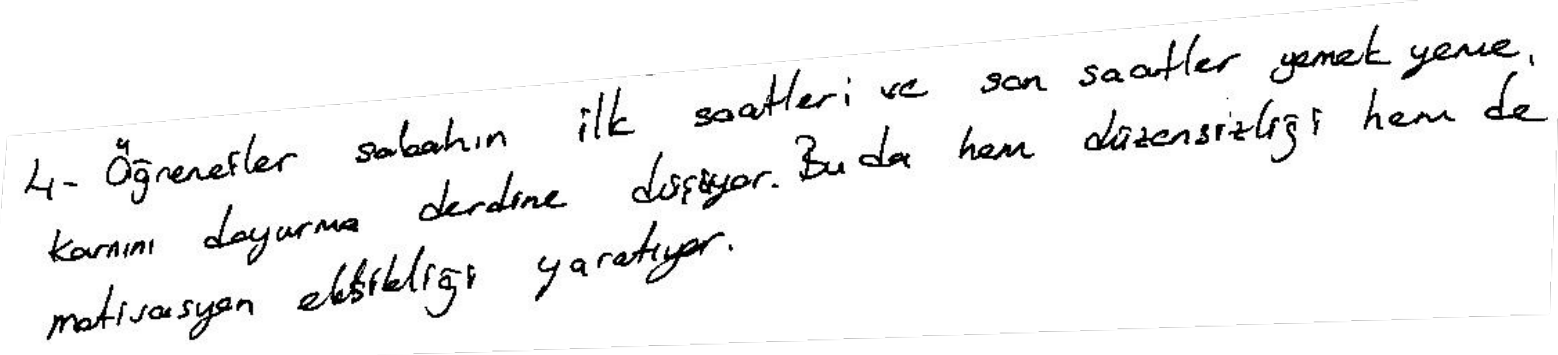

Tablo 31: "Öğrenci başarısı bu yıl içinde düşmeye başlamışstır.” Maddesine Ait Yüzde ve Frekanslar

\begin{tabular}{lll}
\hline Ölçekler & Frekans (f) & Yüzde (\%) \\
\hline Katılmıyorum & 34 & 30.1 \\
Kararsızım & 34 & 30.1 \\
Katılıyorum & 45 & 39.8 \\
Toplam & 113 & 100 \\
\hline
\end{tabular}

Tablo 31'de araştırmaya katılan öğretmenlerin \%39.8'i bu yıl içinde öğrenci başarısının düşmeye başladığını belirtmiştir. Araştırmaya katılan öğretmenlerin çoğunluğu beşinci sınıf öğrencilerinin ortaokula geçmesiyle başarının düştüğünü söylemiştir.

Öğretmen yirmi yedi

$$
\begin{aligned}
& \text { 1-5. sinif o'grencileri dönüsüm doneminde olduklor } \\
& \text { iain not ortalarralari ve uyum durumlarinda } \\
& \text { dinsise sebep dat. }
\end{aligned}
$$

TARTIŞMA ve SONUÇ

$\mathrm{Bu}$ araştırma kapsamında devlet ortaokullarda görev yapan branş öğretmenlerinin, 5.sınıfların ortaokul kapsamına alınması sonrasında sadece 5.sınıflarda yaşadığı problemler ve karşılaştıkları güçlükler ile ilgili görüşlerine başvurulmuştur. Öğretmenlerin görüşleri, öğrenci kaynaklı, öğretmen kaynaklı ve diğer etmenler olmak üzere üç ana faktör altında incelenmiştir. Uygulanan anketin Cronbach's Alpha katsayısı $0.86(\alpha=.862)$ olarak hesaplanmıștır. Bu doğrultuda;

Öğrenci kaynaklı olduğu düşünülen sorunlar kısaca, öğrencilerin yaşlarının küçük olduğu, kendilerini ilkokul gibi hissettikleri, ergenlik çağındaki çocuklarla bir arada olmalarının sakıncalı olabileceği, derslere ilgisiz oldukları, motivasyon ve dikkat eksikliği sorunları olduğu, davranış bozuklukları sergilendiği yönündedir. Öğretmenler "derslere ilgi göstermiyorlar", "yaşları ortaokul olmaya uygun değil", "alışma süreleri daha uzun oldu", "erken saatte okula gelmeye alışamadılar", "çok öğretmene alışmakta zorlanıyorlar" şeklinde görüş belirtmişlerdir.

Öğretmen kaynaklı sorunlar olarak kısaca, öğrencilerin davranışlarını yönetememe (sınıf ve davranış yönetimi), ders anlatım yöntem ve tekniklerinde hissedilen eksiklikler, haftalık ve günlük ders saatlerinin fazlalığı ile derslere giriş-çıkış saatleri şeklinde yoğunlaşmıştır. Öğretmenlerin genel görüşü 5.sınıfların ilk sömestrde geçiş dönemi yaşadıkları yönünde olmuştur. Bununla beraber bu sürecin bir dönemde aşıldığı ve hemen hemen normale döndüğü belirtilmiştir. Öğretmenler "öğrenciler ile tek tek ilgilenemiyorum", "onların seviyesine inmekte güçlük çekiyorum”, "derslere ilgilerini çekemiyorum" şeklinde görüş bildirmişlerdir. 
Diğer etmenler olarak kısaca ders saatlerinin fazlalığı, giriş çıkış saatlerinin uygun olmayışı, ders kitapları ve müfredat programının uygun olmadığı ve son olarak açlıkla başedememe olarak dile getirilmiştir. Öğretmenler sorunları genel anlamda "yedi ders saati fazla", "okula giriş saati çok erken", "müfredat yetersiz", "ders kitaplarında soyut kavramlar çoğunlukta”, "öğrenciler erken saatlerde geldiklerinden açlıkla başedemiyorlar" șeklinde görüş bildirmişlerdir.

Nicel olarak elde edilen veriler ise aşağıda, öğretmenlerin katılıyorum cevabını seçtikleri maddelerin yüzde olarak en yüksek olanı önce olacak șekilde sıralanmıștır.

Öğrenci kaynaklı olduğu düşünülen sorunlar; 1)Öğrencilerin çocuksu davranışları çok fazla (\%84,1), 2)Kendilerini ilkokul gibi hissederler (\%77), 3)Ergenlik dönemindeki öğrenciler ile aynı ortamda olmaları uygun değil $(\% 73,5), 4)$ Öğrenciler daha somut dönemdedir $(\% 63,7), 5)$ Üst sinıf öğrencileri aynı ortamda olmaya yaşları uygun değil $(\% 2,8), 6)$ Çok sayıda öğretmene alışmakta zorlanırlar $(\% 57,5), 7)$ Yoğun tempodan sıkılıyorlar $(\% 55,8)$, 8)Üst sinıflara göre fazla ayrıntı soruyorlar (\%54,9), 9)Üst sınıflar gibi sorumluluk alamıyorlar $(\% 53,1), 10)$ Derse odaklanma ve dikkat sorunu yaşarlar (\%50,4), 11) Özgüven eksikliği yaşıyorlar (\%28), 12) Başarısızlık korkusu yaşarlar $(\% 27,4)$ șeklinde sıralanmaktadır.

Öğretmen kaynaklı olduğu düşünülen sorunlar; 1)Yaşları ilkokul olmaya daha uygundur (\%61,1), 2) Birebir ilgi göremediklerinden okula yabancılaşırlar (\%36,3), 3) Branş öğretmeni açığı vardır $(\% 31,9)$, 4) Disiplin sorunları yaşıyorum $(\% 27,4), 5)$ Sorunlarla başedemiyorum $(\% 23,9), 6)$ Öğrencilerin ilgi ve ihtiyaçlarına cevap veremiyorum (\%23), 7)Ders saati fazla olduğu için verimli olamıyorum (\%23), 8) Sabırlı ve anlayışlı değilim (\%18,6), 9) 5.sınıfların dersine girerken isteksizim $(\% 16,8), 10)$ Seviyelerine inmekte zorlanıyorum $(\% 16,8), 11)$ Öğrencileri değerlendirirken sorun yaşarım $(\% 14,2), 12)$ Branş öğretmenleri hakkındaki algıları olumsuzdur $(\% 12,4)$ şeklinde siralanmaktadır.

Diğer etmenler olarak; 1)Sık sık acıkmaktadırlar (\%70,8), 2)Giriş- çıkış saatleri uygun değildir $(\% 67,3), 3) 7-8$ ders fazla gelmektedir $(61,1), 4)$ Ders kitaplarında soyut kavramlar çoktur $(\% 40,7)$, 5)Akademik başarıları 5.sınıfta düşmüştür $(\% 39,9), 6)$ Konular seviyelerine uygun değildir $(\% 28,3)$ şeklinde sıralanmaktadır.

Verilen cevaplara geniş çerçeveden bakıldığında, öğretmenlerin 5.sınıflar düzeyinde ders vermeye alışkın olmadıkları hissedilmektedir. Bu durum aslında normal bir durum olup, daha önceki yaşantılarında da öğretmenlerin birçoğunun (fen bilgisi, sosyal bilgiler, matematik, türkçe) 5.sınıf düzeyinde ders işlemediği veya buna uygun eğitim almadığı düşünülebilir. Yapılan değişiklik sonucunda yaşanan bocalama normal olmakla beraber, öğretmenler tarafından da açıkça belirtilmektedir. Bu durumun öğretmenler deneyim kazandıkça daha önemsiz hale gelmesi beklenebilir. Öğrencilerin yaşları büyüdükçe de bazı sorunların üstesinden gelinmesi daha kolay bir hal alması beklenir.

Öğretmenlerin beşinci sınıfların daha çocuksu olduklarını düşünmeleri aslında daha farklı davranıșlarla karşılaștıklarının bir göstergesidir. Bu düșünceden hareketle de 5.sınıf öğrencilerinin ergenlik dönemindeki öğrenciler ile uyum sağlayamadıklarını düşünüyor olabilirler. Aynı şekilde ders anlatımlarında yaşanan sorunlar, seviyelerine inmekte zorlanma durumlarının varlığı ve sınıf yönetimi problemlerinin varlığı aslında beşinci sınıfların diğer sınıflara göre daha farklı davrandığına bir kanıt olabilir. Benzer olarak gelişim basamakları ve davranış şekilleri ile ilgili de bir ipucu vermektedir. Bu durumlara açlıkla baş edememe, çokça şikayet etme, motive olamama, sınıf içi problemler, öğretmenlere alışamama, dersleri anlayama gibi durumları örnek gösterebiliriz.

Şikayet etme davranışı ile ilgili Özer ve arkadaşları (2005) yaptıkları araştırmada; a) En iyi sınıflarda bile öğrencilerin şikayet etme davranışlarının normal olduğu, b)Şikayet etme davranışının öğretmen davranışları ile pekiştirildiği, c) Sosyal bir ortamda çıkan sorunların, herhangi bir gereksinimin karşılanmaması sebebiyle ortaya çıktığı, ç) Kıdem yılı 15 yıldan az olan öğretmenlerin sınıf yönetimi ve otorite sağlamada daha yetersiz kaldıkları dolayısıyla şikayet davranışlarının daha sık görülebileceği bulgularına ulaşmışlardır (Özer, Gelen ve Kahramanoğlu, 2005). Bu durum da aslında şikayet etme davranışının 5.sınıf öğrencilerine has bir durum olmadığı, öğretmenlerin sınıf yönetimi konusundaki eksikliklerinin de bu duruma sebep olabileceğinin bir göstergesidir.

Topçu ve Kabasakal'ın (2010) başka bir sorun olan saldırganlık davranışlarını inceleyen araştırmalarında, bu davranışlarının en sık yaşandığı sınıf olarak 5.sınıf, en az yaşandığı sınıf olarak da 8.sınıflar belirtilmiştir. 4.sınıfların en az saldırganlık davranışı gösterdiği ancak daha yüksek 
oranda saldırganlık davranışına maruz kaldığı yönünde bulgulara ulaşılmıştır (Baş ve Kabasakal, 2010). Bu noktadan hareketle öğretmenlerin sorun olarak gördükleri bir durumun aksine (5.sınıfların farklı binaya geçmiş olması) aslında 4.sınıflar lehine bir durum olarak görülebilir. Bu sayede en az saldırganlık davranışı görülen 4.sınıflar ve daha küçük yaştaki öğrenciler saldırganlık davranışlarından bir nebze olsun uzaklaşmış olabilir. Başka bir deyişle yapılan sistem değişikliği bu yönde olumlu bir adım olarak görülebilir.

Bir diğer husus ise ders saatlerinin fazlalığı ve giriş-çıkış saatlerinin uygun olmadığı yönündeki görüşlerin yoğunluğudur. Öğrencilerin de öğretmenlerin de bu yönde şikayetleri olduğu görülmektedir. Ancak bu durumun kişisel yargılar ile değerlendirilmesi yanında bilimsel metodla desteklenmesi de uygun olacaktır. Örneğin, "Erken derse başlamanın öğretmen davranışlarına, öğrenci motivasyonuna, öğrenci dikkatine ve başarısına etkisi var mıdır?” gibi sorular soran bilimsel araștırmalar bu konuda daha da derin kavrayıș elde etmemizi sağlayacaktır. Daha önce yapılan bir değerlendirme araştırmasında benzer bulgular elde edilmiştir (Eğitim-Bir Sen., 2013). Bununla beraber araștırma kapsamında elde edilen veriler hem öğretmenlerin hem de öğrencilerin erken saatte derse başlamaları ve öğrencilerin 7-8 saat ders yapmaları zorlayıcı bir durum olarak görülmektedir.

Açlık konusunda belirtilen görüşler ise dikkat çekicidir. Öğretmenler genel olarak öğrencilerin erken saatte okula gelmeleri dolayısıyla kahvaltı yapmamaları ve daha sonraları sık sık acıktıkları yönünde sorunlar dile getirmişlerdir. Şimşek ve arkadaşları (2009) ilköğretim öğrencilerinin genelinin yeme ihtiyaçlarının büyük kısmını okulda karşıladıklarını belirttikleri ve 5.sınıflar (n=173) ile yapmış oldukları araştırmada, öğrencilerin büyük çoğunluğunun $(\% 79,2)$ "acıktıkları" yönünde görüş bildirildiğini dile getirmişlerdir (Şimşek, Yabancı ve Turan, 2009). Bu doğrultuda ele alınacak olursa, belirtilen araștırmanın bulguları öğretmen görüșleriyle paralellik göstermektedir. Bununla beraber Demircioğlu ve Yabancı'nın (2003) bilişsel gelişim ve beslenme ile ilgili yapmış olduğu araştırmada özellikle de kahvaltının öğrenme sürecine olumlu etkilerinden bahsedilmektedir. Bu etkiyi kandaki glikoz yoğunluğu ve beyinin glikoz ihtiyacı ile açılayarak kahvaltı yapma ile bilişsel işlemler arası ilişkiye dikkat çekilmiştir (Demircioğlu ve Yabancı, 2003). Benzer şekilde 6., 7. ve 8. sınıfları kapsayan Hoyta ve Şanlıer'in (2007) ikinci kademe öğrencilerin beslenme alışkanlıkları üzerine yaptıkları araștırmada verdikleri önerilerden ikisi araştırma bulgularını destekler görünmektedir. Bu öneriler: 1) Çocukların geçmişten itibaren düzenli beslenme alışkanlığına sahip olmadığı ihtimali üzerine okul çalışanlarının bu konuda tedbirler almasının olumlu olacağı, 2) Çocuğa zamanı iyi kullanma alışkanlığı kazandırılarak, çocuğun yatma ve kalkma saatlerini, okula geliş saatlerini, oyun ve ders çalıșma saatlerini düzene koyduğunda, "okula geç kalırım" korkusu ile kahvaltı ögününü atlamasına engel olunabileceği şeklindedir (B., Hoyta ve Şanlıer, 2007).

Son olarak öğretmenlerin öğrenciler ve diğer etmenler ile ilgili sorunlara/maddelere yüksek oranda "katılıyorum" cevabı vermeleri yanında, öğretmen kaynaklı veya öğretmenden kaynaklanabilecek sorunlara/maddelere yüksek oranda "katılmıyorum" cevabı vermeleri dikkat çekicidir. Bu durum aslında, öğretmenlerin yaşanan sorunların düşük bir bölümünün kendilerinden kaynaklandığını, büyük oranda ise öğrenci ve diğer etmenlerin sorunların oluşmasında etkili olduğunu düşündüğünü gösteriyor olabilir. Başka bir deyişle öğretmenler yaşanan problemlerin büyük bölümünü kendi kontrolleri dışında görmektedirler. Çelikkaleli ve arkadaşları (2009) istenmeyen davranıșların nedenlerini öğretmenlerin $(n=503)$ görüşlerine göre değerlendirmișlerdir. $\mathrm{Bu}$ araștırmada öğretmenlerin belirttiği istenmeyen davranış nedenlerinin (n =9) başında "öğrencilerin aileleri ve aile yapıları $(x=7,26)$ " gelirken, "öğretmenlerin sahip oldukları özellikler $(\mathrm{x}=3,49)$ " 8.sırada, "Dünya'daki siyasi ve ekonomik gelişmeler $(\mathrm{x}=3,44)$ " ise 9.sırada yer almaktadır (Çelikkaleli ve diğerleri, 2009). Son sıradaki "Dünya'daki siyasi ve ekonomik gelişmeler" maddesiyle "öğretmenlerin sahip oldukları özellikler" maddesinin yakın ortalama ve benzer sıralamaya sahip olması da dikkat çekicidir. Bu bağlamda her iki araștırma verileri de öğretmenler açısından benzeşmektedir. Bizim görüşümüz ise, öğrencilerin ve ailelerinin davranışsal ve gelişimsel olarak sorunlara neden olabileceği ancak öğretmenlerin de mesleki, kişisel ve düşünsel olarak sorunlara benzer șekilde etki edebileceği yönündedir.

Sonuç olarak, 4+4+4 sistemi olarak yapılan değişimlere öğrencilerin bir nebze alışamadığı görülse de, benzer şekilde öğretmenlerin de karşılaştığı veya karşılaşacağı durumlara hazırlıksız 
oldukları görülmektedir. Öğretmenler ise her sene 5.sınıfa ders vereceklerinden karşılaştıkları soruna çözüm üretmeleri veya bu sorunu ortadan kaldıracak strateji geliştirmeleri beklenir. Öğretmenler zamanla farklı yöntemler geliștirerek 5.sınıf düzeyine daha uygun hale gelebilirler. Bunun yanında öğretmenlere davranış bilimi ve sınıf yönetimi hususunda eğitim verilmesi veya destek sağlanması düşünülebilir. Aynı zamanda branş öğretmenlerinin mümkünse sınıf öğretmenlerinden yardım almaları 5.sınıf düzeyinde ders anlatımı ve bu gibi sorunları aşmalarında fayda sağlayabilir.

Öğrenciler için zamanla alınan dönütler, karșılașılan sorunlar ve hatta yapılacak araștırmalar sonucunda elde edilen veriler ışığında iyileştirmeler yapılması uygun olacaktır. Gelişimlerine ve yaşadıkları problemlere uygun destek sağlanarak sorunların üstesinden gelmelerinde yardımcı olunabilir. Zira öğretmenler tarafından erken saatte okula gelmek, 6 saatten fazla derse girmek, kısa teneffüs yapmak, sık acıkmaları gibi durumlar öğrenciler için zorlayıcı durumlar olarak görülmektedir. Sorumluluk alamama, ödevlerini yapmama gibi davranışlar da seviyelerine uygun ödevlerle ve yerine getirebilecekleri sorumlulukların, basitten zora doğru basamaklandırılması yoluyla öğrencilere kazandırılabilir.

Alınan öğretmen görüşleri aslında daha genel ve daha derinlemesine yapılacak araștırmaların gerekliliğini ortaya koymaktadır. Hem öğretmenler hem de öğrenciler ile yapılacak araştırmalar sonucunda bir yargıya varmak daha doğru olacaktır. Yaşanan sorunların beklenmeyen bir değișiklikten mi, yoksa öğrencilerin yașları, gelişim düzeyleri ve bilişsel basamakları dolayısıyla mı olduğu sorularının cevapları ancak bu sayede ortaya konabilir.

\section{KAYNAKÇA}

Akpınar, B., Dönder, A., Yıldırım, B. ve Karahan, O. (2012). Eğitimde 4+4+4 Sisteminin (Modelinin) Karşıt Program Bağlamında Değerlendirilmesi. Marmara Üniversitesi, Atatürk Eğitim Fakültesi, 36 (36), 25-39.

Akyüz, Y. (1994). Türk Eğitim Tarihi (Başlangıçtan 1993 'e) İstanbul: Kültür Koleji Yayınları.

Arslan, M. (2000). Cumhuriyet Dönemi İlköğretim Programları ve Belli Başlı Özellikleri. Milli Eğitim Dergisi, 146.

Bakioğlu, A., Özcan M., Baltacı, R., Elverici, S, Göçmen, G., Pekince, D., Altay Gökmen, İ., Ülker, N.(2013). Karşılaştırmalı Eğitim Yönetimi. 2.Basım. Nobel: Ankara.

Baş, A., U. ve Kabasakal, Z., T. (2010). İlköğretim Okullarında Saldırganlık ve Şiddet Davranışlarının Yaygınlığı. Ilkögretim Online, 9 (1), 93-105.

Creswell, J. W. Ve Plano Clark, V.L. (2007). Desining and Cunducting Mixed Methods Research. Thousand oaks, CA: Sage

Cüceloğlu, D. (1991). Insan ve Davranışı. 2. Baskı. İstanbul: Remzi Kitabevi.

Çelikkaleli, Ö., Balcı, F., A., Çapri, B. ve Büte, M. (2009). İlköğretim Öğretmenlerinin İstenmeyen Öğrenci Davranışlarının Nedenleri Üzerine Görüşleri. Illköğretim Online, 8(3), 625-636.

Demircioğlu, Y. ve Yabancı, N. (2003). Beslenmenin Bilişsel Gelişim ve Fonksiyonları ile İlişkisi. Hacettepe Üniversitesi Ĕ̈itim Fakültesi Dergisi, 24, 170-179.

Demirel, Ö. (1992). Türkiye' de program geliştirme uygulamaları. H.̈̈. Eğitim Fakültesi Dergisi, 7, 27-43.

Eğitim-Bir Sen. (2012). 4+4+4 Yeni Eğitim Sistemi Ne Getiriyor? Neler Olmalı?. (Online) www.egitimbirsen.org.tr/ adresinden 01.01.2015 tarihinde edinilmiştir.

Eğitim-Bir Sen. (2013). Birinci Yılını Dolduran 4+4+4 Eğitim Sistemine İlişkin En Kapsamlı İzleme ve Değerlendirme Çalışması. (Online) www.egitimbirsen.org.tr/ adresinden 10.11.2014 tarihinde edinilmiştir.

Eğitim-Bir Sen. (2013). 4+4+4 Eğitim Reformunu İzleme Raporu. Ankara: Hermes Ofset.

Erden, M. ve Akman, Y. (2007). Ĕgitim Psikolojisi. Ankara: Arkadaş Yayınevi.

Ergün, M. (1999). Ë̆itim Felsefesi. Ankara: Ocak Yayınları

Fer, S. (2005). 1923 yılından günümüze Cumhuriyet Dönemi ilköğretim programları üzerine bir inceleme. Cumhuriyet Dönemi Ĕ̆itim Politikaları Sempozyumu: İstanbul.

Gelen, İ ve Beyazıt, N. (2007). Eski ve yeni ilköğretim programları ile ilgili çeşitli görüşlerin karşılaştırılması. Kuram ve Uygulamada Ĕ̈itim Yönetimi, 51, 457-476.

Genç, S., Z. (2007). Cumhuriyet’ten günümüze ilköğretimde program geliştirme çabaları. A.̈̈. Bayburt Ĕ̌gitim Fakültesi Dergisi, 2 (2), 123-137.

Güven, İ. (2010). Türk Eğitim Tarihi. Naturel Yayınları, Ankara.

Güven, İ. 2012. Eğitimde 4+4+4 ve Fatih Projesi Yasa Tasarısı = Reform mu?. Ilköğretim online 11(3), 556-577.

Gür, S., B., Özoğlu, M. , Coşkun, İ., Görmez, M. (2012). 2012' de Eğitim. Seta Analiz, 58, 3-20. (Online) http://file.setav.org/ adresinden 09.11.2014 tarihinde edinilmiştir.

Hakbilen, N. (1984). İlkokul Çağı Çocuklarının Başarılarını Etkileyen Faktörlerin İncelenmesi. Yayınlanmamış Doktora tezi. Hacettepe Üniversitesi Sağlık Bilimleri Enstitüsü, Ankara. 
Hoyta, B., A. ve Şanlıer, N. (2007). İlköğretim 6., 7. ve 8. Sınıf Öğrencilerinin Beslenme Davranışları ve Sosyal Onaylanma İsteği. Milli Ĕ̈itim Dergisi,174,193-205.

Huczynski, A. ve Buchanan.(1991). Organizational Behaviour. Prentice Hall International (UK) Ltd. New York. Kazanc1, O. (1989). Eğitim Psikolojisi. Ankara: Kazancı Kitap Ticaret A.Ş.

Koçer, H., A. (1988). Türkiye'de Modern Eğitimin Doğuşu ve Gelişmesi. Uzman Yayınları. Ankara,

Meb (2012). "On iki Yıllık Zorunlu Eğitim: Sorular Cevaplar". Ankara

Meb (2012). “12 Yıllık Zorunlu Eğitime Yönelik Uygulamalar”. 2012/20 No'lu Genelge. Özel Kalem Müdürlüğü: Ankara.

Özdemir, S. (2000). Ĕ̌itimde örgütsel yenileşme. Ankara: Pegema

Özer, B., Gelen, İ.,Kahramanoğlu, R. (2010). İlköğretim İkinci Devre Öğrencilerinin Şikayet Etme Davranışlarının Öğretmen, Öğrenci ve Veli Görüşleri Doğrultusunda Değerlendirilmesi. Gaziantep Üniversitesi Sosyal Bilimler Dergisi, 9(2), 425-457.

Seçer, Z., Çağdaş, A. ve Seçer, F. (2006). Çocukların Okul Ortamındaki Ahlaki ve Sosyal Kuralları Ayırtetme Becerisinin Çeşitli Değişkenler Açısından İncelenmesi. Pamukkale Üniversitesi Eğitim Fakültesi Dergisi, 20.

Selçuk, Z. (1994). Eğitim Psikolojisi. Ankara: Atlas Kitabevi.

Sprinthall, A.N. ve Sprinthall, R. C. (1990). Educational Psychology. 5.Edition. New York: McGraw-Hill Company.

Şimşek, I., Yabancı, N. ve Turan, Ş. (2009). Okul Çağı Çocuklarının Beslenme Çantalarının Değerlendirilmesi. Aile ve Toplum Ĕ̈itim Kültür ve Araştırma Dergisi,11-5(19), 99-110.

Tashakkori, A. ve Teddlie, C. (1998). Mixed Methodology: Combining Qualitative and Quantitative Approaches. Tousand Oaks, CA: Sage.

Yavuzer, Y., Demir, Z. ve Çalışkan, M., (2000). Gelişim ve Öğrenme Psikolojisi. Konya: Mikro Yayınevi. 